\title{
ANALISIS ATP-WTP TERHADAP TARIF KRL LINTAS TANAH ABANG- RANGKASBITUNG (STUDI KASUS: STASIUN JURANG MANGU)
}

\author{
Felix Casey Ignatius ${ }^{1}$, Dewi Linggasari², dan Hokbyan Angkat ${ }^{3}$ \\ ${ }^{1}$ Program Studi Sarjana Teknik Sipil, Universitas Tarumanagara, Jl. Letjen S. Parman No.1 Jakarta \\ felixi.ts@stu.untar.ac.id \\ ${ }^{2}$ Program Studi Sarjana Teknik Sipil, Universitas Tarumanagara, Jl. Letjen S. Parman No.1 Jakarta \\ dewil@ft.untar.ac.id \\ ${ }^{3}$ Program Studi Sarjana Teknik Sipil, Universitas Tarumanagara, Jl. Letjen S. Parman No.1 Jakarta \\ hokbyan@gmail.com
}

Masuk: 06-07-2020, revisi: 28-07-2020, diterima untuk diterbitkan: 30-07-2020

\begin{abstract}
Determination of public transport fares needs to be compared to the value of the Ability to Pay (ATP) and Willingness to Pay (WTP) of Kereta Rel Listrik (KRL) service users to pay a sum of money for the services received. The purpose of this study is to analyze the amount of ATP and WTP value of Green Line KRL services' users, especially those through the Jurang Mangu Station. Primary research data collection methods through surveys with online questionnaire to respondents who have used the Green Line KRL. The research data obtained will be processed and analyzed to obtain the results of respondents' characteristics, ATP values, and WTP values. The analysis results on the existing tariffs of KRL Green Line with a base rate of Rp. 3.000,- shows the value of ATP and WTP of Rp. 5.057,and $R p .4 .825,-$. The ATP and WTP values respectively for those going through the Jurang Mangu Station are Rp. 5.167,- and Rp. 4.875,-. The results of this study indicate that the ATP value is lower when compared to the WTP value, but this ATP value is greater than the existing tariff. This data shows that the current tariff is proportional to the service received.
\end{abstract}

Keywords: Ability to Pay; Willingness to Pay; Tariff; KRL Green Line

\begin{abstract}
ABSTRAK
Penetapan tarif angkutan umum perlu dibandingkan nilai Ability to Pay (ATP) dan Willingness to Pay (WTP) pengguna jasa Kereta Rel Listrik (KRL) untuk membayar sejumlah uang demi pelayanan jasa yang diterima. Tujuan dari penelitian ini adalah untuk menganalisis besaran nilai ATP dan WTP pengguna jasa KRL pada lintas Green Line khususnya yang melalui Stasiun Jurang Mangu. Metode pengumpulan data penelitian secara primer melalui survei dengan panduan kuesioner secara online kepada responden yang pernah menggunakan KRL Green Line. Data penelitian yang diperoleh akan diolah dan dianalisis untuk mendapatkan hasil karakteristik responden, nilai ATP, dan nilai WTP. Hasil analisis pada tarif eksisting KRL Green Line dengan tingkat tarif dasar Rp. 3.000,- didapat nilai ATP dan WTP masing-masing adalah Rp. 5.057,- dan Rp. 4.825,-. Nilai ATP dan WTP untuk yang melalui Stasiun Jurang Mangu masing-masing adalah Rp. 5.167,- dan Rp. 4.875,-. Hasil penelitian ini menunjukkan bahwa nilai ATP lebih rendah jika dibandingkan dengan nilai WTP, tetapi nilai ATP ini lebih besar daripada tarif eksisting. Data ini menunjukkan bahwa tarif yang berlaku saat ini sebanding dengan pelayanan yang diterima.
\end{abstract}

Kata kunci: Ability to Pay; Willingness to Pay; Tarif; KRL Green Line

\section{PENDAHULUAN}

Persaingan antar moda transportasi yang semakin ketat menuntut penyelenggara angkutan kereta Commuter Line untuk selalu melakukan perbaikan pelayanan dan menawarkan keunggulan dibandingkan moda transportasi yang lain. Kereta api merupakan moda transportasi yang mampu mengangkut penumpang dengan kapasitas besar untuk menempuh jarak jauh dalam waktu yang relatif cepat. Kereta api diperuntukkan bagi masyarakat luas sebagai penunjang roda perekonomian, termasuk di dalamnya masyarakat ekonomi lemah. Salah satu keunggulan kereta Commuter Line ini adalah sebagai angkutan umum yang mampu memberikan pelayanan transportasi yang efisien, cepat dan murah. 
Kereta Commuter Line merupakan angkutan umum yang diminati dan dinilai dapat menjadi solusi dalam mengatasi kebutuhan masyarakat untuk menghindari akibat dari kemacetan di wilayah Jabodetabek (Jakarta, Bogor, Depok, Tangerang, Bekasi) sehingga diperlukan adanya kebijakan tarif. Kebijakan tarif harus mempertimbangkan sisi pengguna jasa (user) dengan harapan adanya peningkatan kualitas pelayanan kereta Commuter Line yang diukur dari persepsi pengguna, tetapi tarif yang akan diterapkan pada kereta Commuter Line memiliki sifat yang krusial dan sensitif. Hal ini disebabkan oleh banyak variabel yang mempengaruhi dan melibatkan kepentingan konsumen sebagai penumpang dan pengelola kereta Commuter Line.

Penetapan tarif angkutan orang perlu ditinjau nilai Ability to Pay (ATP) dan Willingness to Pay (WTP) pengguna jasa kereta untuk membayar sejumlah uang demi pelayanan jasa yang diterima. Besaran nilai ATP menjelaskan suatu nilai total atau maksimum yang dipikirkan oleh pengguna terhadap suatu barang atau jasa. Tingginya nilai ketersediaan untuk membayar jasa transportasi dapat dipengaruhi oleh satu atau lebih karakteristik sosial ekonomi, yakni usia, jenis kelamin, pendapatan dan lainnya. Besaran nilai WTP mempengaruhi kualitas pelayanan yang diterima oleh pengguna jasa transportasi tersebut. Kualitas pelayanan ini sebagai bentuk usaha untuk memenuhi kebutuhan dan keinginan pelanggan untuk mengimbangi harapan pengguna (Sitorus, Fassa dan Nurhidayah).

Penyedia jasa transportasi harus mengikuti Standar Pelayanan Minimum (SPM) yang telah ditetapkan. Sistem tiket kereta Commuter Line ini diketahui menggunakan tarif progresif yaitu untuk 25 kilometer pertama sebesar Rp. 3.000,00 dan akan ditambah Rp 1.000,00 setiap 10 kilometer berikutnya. Pemberlakuan tarif progresif tersebut mendorong penulis untuk melakukan penelitian terkait Ability to Pay (ATP) dan Willingness to Pay (WTP) terhadap tarif KRL lintas Tanah Abang-Rangkasbitung (Studi Kasus: Stasiun Jurang Mangu). KRL Green Line merupakan pelayanan KRL yang melayani lintas Tanah Abang-Rangkasbitung, sehingga pada kelanjutan penelitian ini lintas Tanah Abang-Rangkasbitung disebut Green Line.

Permasalahan yang akan diteliti perlu diperjelas, maka perumusan masalah penelitian adalah sebagai berikut:

- Berapa besaran nilai Ability to Pay (ATP) dan Willingness to Pay (WTP) pengguna jasa KRL Green Line?

- Bagaimana pengaruh ATP dan WTP pengguna jasa KRL Green Line terhadap tarif?

Tujuan penelitian yang ingin dicapai dalam sebuah penelitian ini adalah sebagai berikut:

- Besaran nilai Ability to Pay (ATP) dan Willingness to Pay (WTP) pengguna jasa KRL Green Line.

- Pengaruh ATP dan WTP pengguna jasa KRL Green Line terhadap tarif.

\section{Tarif}

Tarif angkutan umum merupakan biaya yang ditetapkan operator sebagai penyedia jasa angkutan umum tersebut untuk dibayar bagi pengguna jasa atas fasilitas yang diterimanya (Siregar). Tarif kereta Commuter Line yang diberlakukan harus lebih rendah dari tarif yang ditetapkan oleh penyelenggara sarana perkeretaapian dan termasuk iuran dana pertanggungan wajib kecelakaan penumpang sesuai dengan ketentuan peraturan perundang-undangan. Selisih tarif menjadi tanggung jawab menteri yang menyelenggarakan pemerintahan di bidang perhubungan dalam bentuk kewajiban pelayanan publik.

Peraturan Menteri Perhubungan Republik Indonesia Nomor PM 36 Tahun 2019 menetapkan tarif kereta Commuter Line seperti dapat dilihat pada Tabel 1.

Tabel 1. Tarif Kereta Rel Listrik (KRL)

\begin{tabular}{cccc}
\hline No. & NAMA & LINTAS & $\begin{array}{c}\text { BESARAN TARIF } \\
\text { (Rp/ORANG) }\end{array}$ \\
\hline 1 & 2 & 3 & 4 \\
\hline a. & KRL & KRL 1-25 Km pertama & 3000 \\
b. & KRL & $\begin{array}{c}10 \text { Km berikutnya dan } \\
\text { berlaku kelipatan }\end{array}$ & 1000 \\
\hline
\end{tabular}

(Sumber: Peraturan Menteri Perhubungan Republik Indonesia Nomor PM 36, 2019)

\section{Ability to Pay (ATP)}

Ability to Pay (ATP) merupakan kemampuan daya beli seseorang terhadap suatu barang atau jasa yang didasari oleh persentase pengeluaran dari pendapatannya (Hariwahyudi, Suprapto dan Malkhamah). Analisis ATP menggunakan pendekatan dengan mendasari pada alokasi biaya untuk transportasi dari pendapatan yang diterimanya (Basuki dan 
Chuadinata). ATP guna untuk menunjukkan kemampuan masyarakat dalam membayar tarif berupa ongkos yang dikenakan untuk perjalanannya hingga sampai tujuannya (Tamin). Beberapa faktor yang mempengaruhi ATP adalah sebagai berikut:

- Besar penghasilan

- Kebutuhan transportasi

- Total biaya transportasi (harga tiket yang ditawarkan)

- Persentase penghasilan yang digunakan untuk biaya transportasi

\section{Willingness to Pay (WTP)}

Willingness to Pay (WTP) berperan sebagai ketersediaan pengguna untuk memberi imbalan dalam bentuk jasa atau uang (Setiyaningsih, Asari dan Idris). WTP mempunyai fungsi pengukur tingkat kepuasan terhadap pelayanan angkutan umum. Nilai WTP ini bila masih berada di bawah nilai besaran ATP maka ada kemungkinan untuk melakukan peningkatan nilai tarif yang berguna untuk perbaikan kinerja pelayanan. Garis besar dari fungsi WTP adalah kesediaan pengguna untuk mengeluarkan imbalan atas jasa yang diperolehnya (Winaya dan Caroline).

Analisis WTP didasarkan oleh persepsi pengguna yang merupakan dasar dari pendekatan terhadap tarif dari jasa pelayanan angkutan umum. Menurut (Fricilia dan Legowo) ada juga permasalahan WTP yang dipengaruhi oleh beberapa faktor, diantaranya adalah:

- Produk yang ditawarkan/disediakan oleh operator jasa pelayanan transportasi

- Kualitas dan kuantitas pelayanan yang disediakan

- Utilitas pengguna terhadap angkutan tersebut

- Penghasilan pengguna

\section{Hubungan ATP dan WTP}

Hubungan ATP dan WTP guna untuk menentukan tarif yang seringkali terdapat benturan antara besaran nilai ATP dan WTP. Menurut (Risdyanto, Nasution dan Hasanah) hubungan antara ATP dan WTP dapat dilihat dari 3 kondisi berikut ini:

- $\quad$ ATP lebih besar dari WTP (ATP > WTP)

Kondisi ini bisa disebut sebagai choiced rider yang dimana memiliki kemampuan membayar yang lebih besar daripada keinginan membayar jasa tersebut. Pengguna pada kondisi ini umumnya mempunyai penghasilan yang relatif tinggi tetapi utilitas terhadap jasa tersebut relatif rendah.

- $\quad$ ATP lebih kecil dari WTP (ATP < WTP)

Kondisi ini bisa disebut sebagai captive rider yang berkebalikan dengan choiced rider, keinginan pengguna untuk membayar jasa tersebut lebih besar dari pada kemampuan membayarnya. Pengguna pada kondisi ini memiliki utilitas terhadap jasa yang sangat tinggi tetapi penghasilannya relatif rendah sehingga keinginan pengguna untuk membayar jasa tersebut lebih dipengaruhi oleh utilitas.

- $\quad$ ATP sama dengan WTP $($ ATP = WTP $)$

Kondisi yang menunjukkan antara keinginan dan kemampuan dalam membayar jasa yang dikonsumsi pengguna tersebut sama karena terjadi keseimbangan utilitas pengguna dengan biaya yang dikeluarkan untuk membayar jasa tersebut.

\section{Penentuan tarif berdasarkan ATP dan WTP}

3 pihak utama dalam menentukan tarif pada sistem angkutan umum, yaitu pengguna (user), operator, dan pemerintah (regulator) (Safitri). Prinsip-prinsip dalam menentukan tarif tersebut adalah sebagai berikut:

- ATP merupakan fungsi dari kemampuan daya beli untuk membayar yang dimana nilai tarif yang diberlakukan tidak melebihi nilai ATP kelompok sasaran. Intervensi/campur tangan pemerintah dalam bentuk subsidi langsung atau silang dibutuhkan bila nilai tarif lebih besar dari nilai ATP, sehingga nilai tarif tersebut sama besarnya dengan nilai ATP.

- WTP merupakan fungsi dari tingkat pelayanan angkutan umum, sehingga bila nilai WTP masih dibawah ATP maka masih dimungkinkan melakukan peningkatan nilai tarif dengan perbaikan tingkat pelayanan angkutan umum. 
Tarif berdasarkan ATP dan WTP dapat dilihat pada Gambar 1.

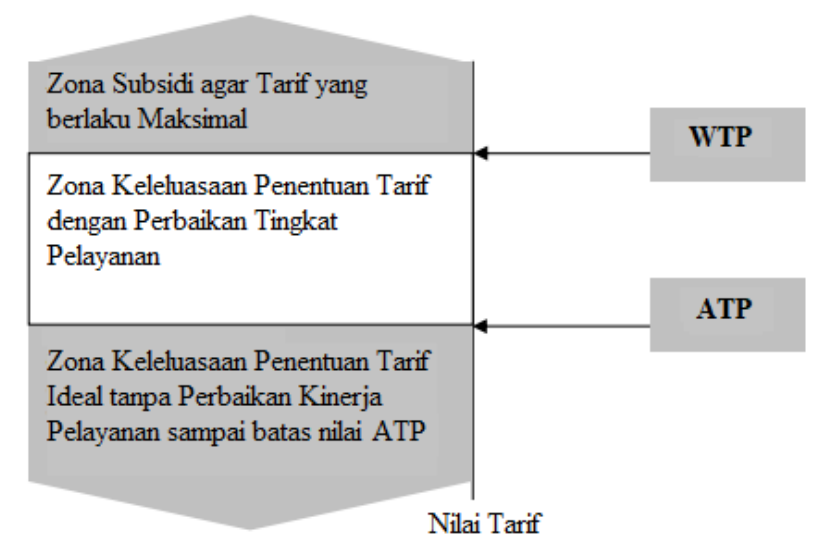

Gambar 1. Tarif berdasarkan ATP dan WTP (Sumber: dardela.com)

\section{METODOLOGI PENELITIAN}

\section{Jenis penelitian}

Jenis penelitian yang dilakukan adalah penelitian deskriptif kuantitatif dengan guna untuk menggambarkan karakteristik responden, besaran nilai ATP, dan besaran nilai WTP pemgguna jasa transportasi KRL Green Line.

\section{Lokasi penelitian}

Lokasi penelitian ini dilaksanakan di Stasiun Jurang Mangu dengan alasan pemilihan lokasi sebagai berikut:

- Stasiun Jurang Mangu merupakan stasiun kelas 3/kecil pada lintas KRL Green Line yang berada di sekitar perbatasan antara Provinsi DKI Jakarta dan Banten.

- Lokasi Stasiun Jurang Mangu berada di dekat pusat perbelanjaan, pemukiman, dan universitas yang dimana berpengaruh pada keberagaman karakteristik pengguna KRL Green Line yang melalui stasiun ini.

- Belum adanya penelitian mengenai ATP dan WTP pengguna jasa KRL Green Line yang melalui Stasiun Jurang Mangu.

\section{Metode pengumpulan data}

Pengumpulan data pada penelitian ini didukung oleh 2 data, yaitu:

- Data Sekunder

Data sekunder pada penelitian ini diambil dari studi dokumentasi yang didapat dari PT. KCI mengenai jadwal dan tarif KRL Green Line.

- Data Primer

Pengambilan data primer penelitian ini didapat dari hasil survei dengan cara menyebarkan kuesioner kepada 100 penumpang KRL Green Line di Stasiun Jurang Mangu. Kuesioner yang dihimpun guna untuk mendapatkan informasi mengenai karakteristik responden, besaran nilai ATP, dan besaran nilai WTP.

\section{Metode analisis data}

Analisis masalah berdasarkan hasil-hasil yang didapat dari pengolahan data terdiri dari analisis karakteristik responden, analisis ATP, dan analisis WTP.

- Analisis Karakteristik Responden

Data karakteristik responden yang diperoleh dari kuesioner kemudian dimasukkan ke dalam tabel rekapitulasi. Data-data yang diperoleh kemudian dapat dianalisis dan ditampilkan dalam bentuk tabel dan grafik.

- Analisis ATP

Data ATP responden yang diperoleh dari kuesioner kemudian dimasukkan ke dalam tabel rekapitulasi. Datadata tersebut dianalisis dan ditampilkan dalam bentuk diagram ATP responden. Nilai besaran ATP responden dihitung dengan menggunakan rumus:

$$
A T P_{\text {rata-rata }}=\frac{i}{n} \sum_{i=1}^{n} A T P_{i}
$$


- Analisis WTP

Data WTP responden yang diperoleh dari kuesioner kemudian dimasukan ke dalam tabel rekapitulasi. Datadata tersebut dianalisis dan ditampilkan dalam bentuk diagram WTP responden. Nilai besaran WTP responden dihitung dengan menggunakan rumus:

$$
W T P_{\text {rata-rata }}=\frac{i}{n} \sum_{i=1}^{n} W T P_{i}
$$

\section{HASIL DAN PEMBAHASAN}

\section{Data responden}

Survei yang dilaksanakan pada penelitian ini secara primer berupa penyebaran kuesioner daring (dalam jaringan) melalui Google Forms. Proses penyebaran kuesioner dilakukan secara online dengan memberikan formulir kuesioner dalam bentuk link kepada responden yang pernah menggunakan KRL Green Line. Pengumpulan data primer yang sudah dilaksanakan diperoleh sebanyak 80 responden KRL Green Line dan sebanyak 13 dari 80 responden melalui Stasiun Jurang Mangu.

\section{Karaksteristik individu responden}

- Jenis Kelamin Data jenis kelamin responden pada penelitian ini dapat dilihat pada Gambar 2 dan Gambar 3.

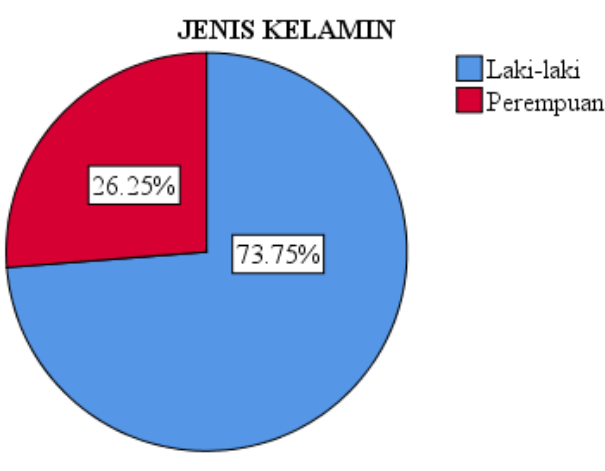

Gambar 2. Jenis kelamin responden KRL Green Line

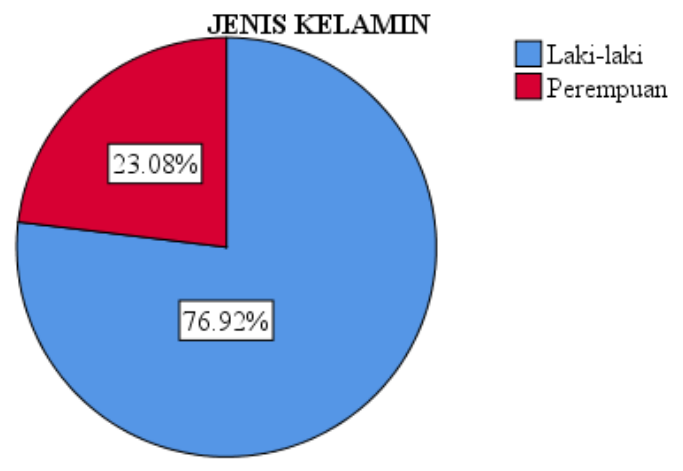

Gambar 3. Jenis kelamin responden pada Stasiun Jurang Mangu

- Usia

Data usia responden pada penelitian ini dapat dilihat pada Gambar 4 dan Gambar 5.

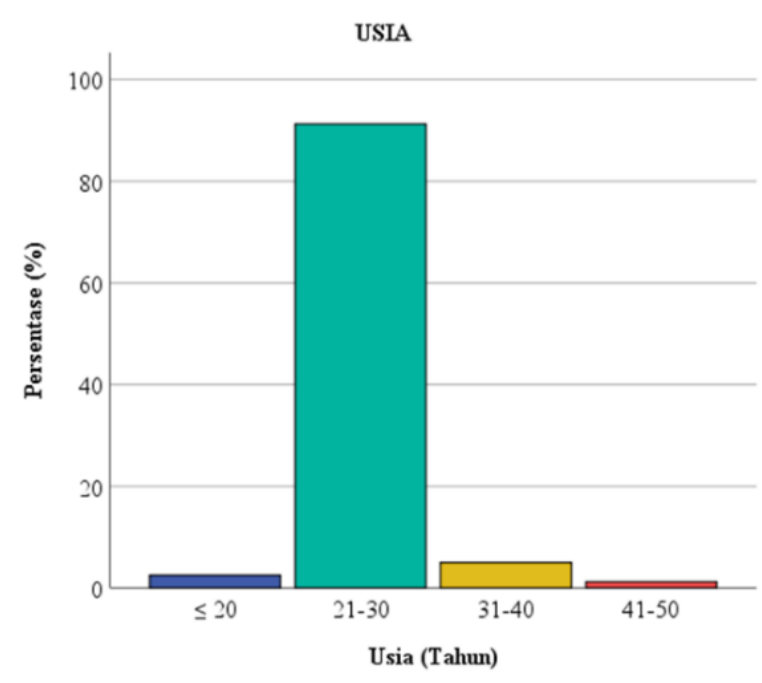

Gambar 4. Usia responden KRL Green Line

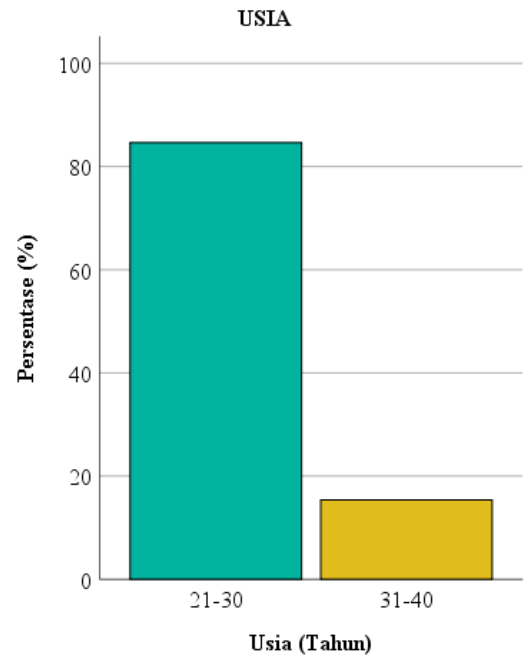

Gambar 5. Jenis kelamin responden pada Stasiun Jurang Mangu 
- Tempat tinggal

Data tempat tinggal responden pada penelitian ini dapat dilihat pada Gambar 6 dan Gambar 7.

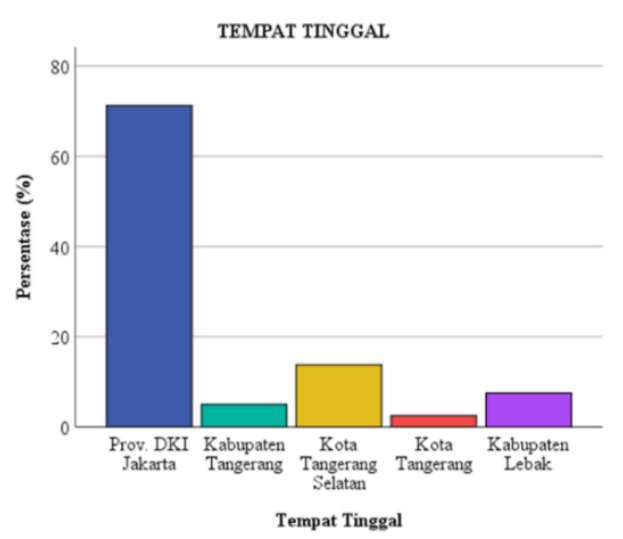

Gambar 6. Tempat tinggal responden KRL Green Line

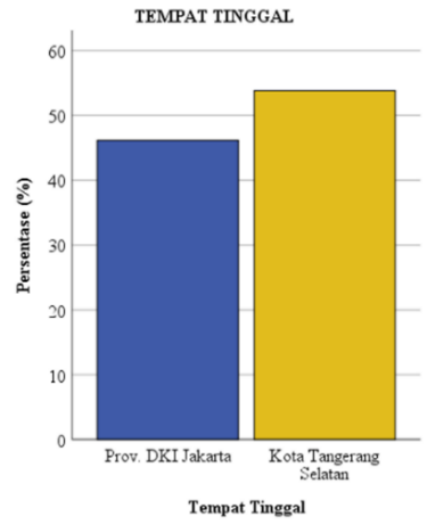

Gambar 7. Tempat tinggal responden pada Stasiun Jurang Mangu

- Pendidikan

Data pendidikan responden pada penelitian ini dapat dilihat pada Gambar 8 dan Gambar 9.

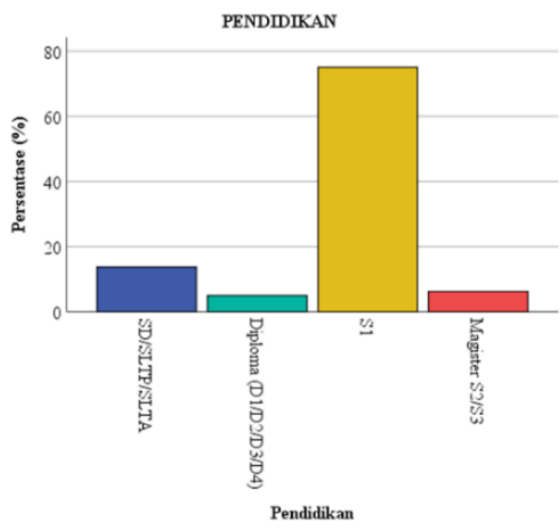

Gambar 8. Pendidikan responden KRL Green Line

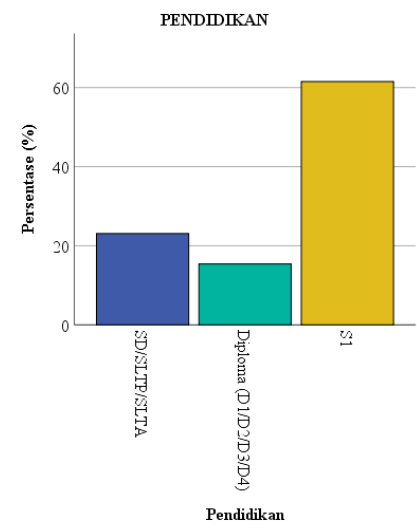

Gambar 9. Pendidikan responden pada Stasiun Jurang Mangu

- Pekerjaan

Data pekerjaan responden pada penelitian ini dapat dilihat pada Gambar 10 dan Gambar 11.

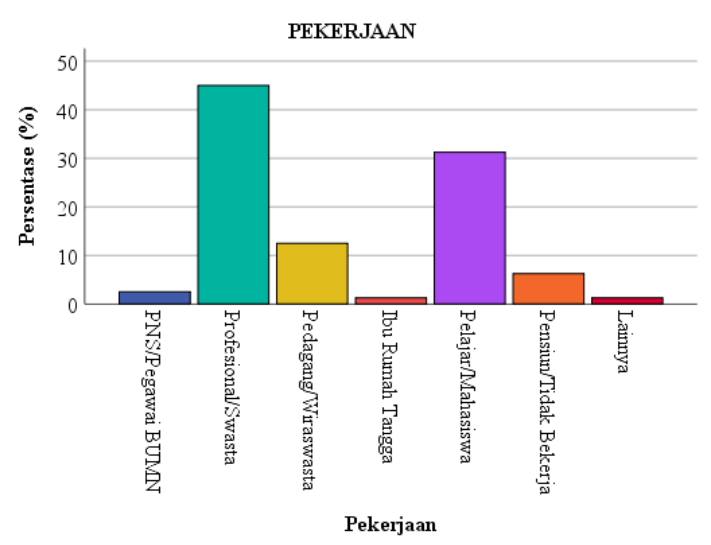

Gambar 10. Pekerjaan responden KRL Green Line

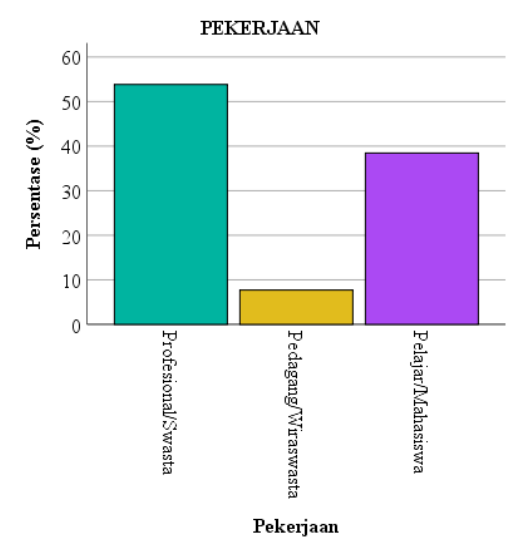

Gambar 11. Pekerjaan responden pada Stasiun Jurang Mangu 
- Penghasilan bulanan

Data penghasilan bulanan responden pada penelitian ini dapat dilihat pada Gambar 12 dan Gambar 13.

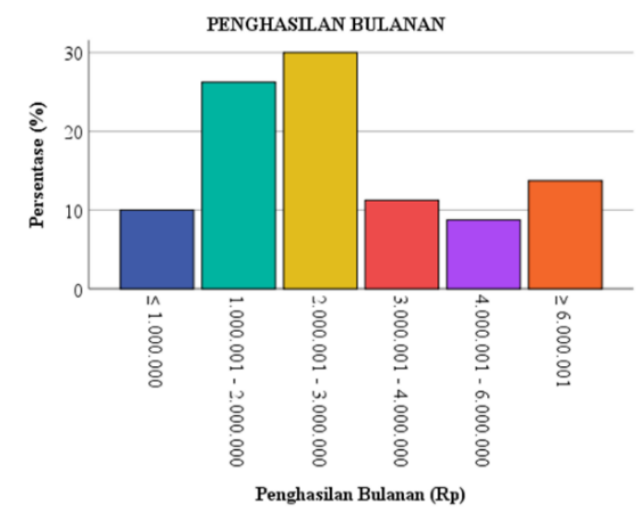

Gambar 12. Penghasilan bulanan responden KRL Green Line

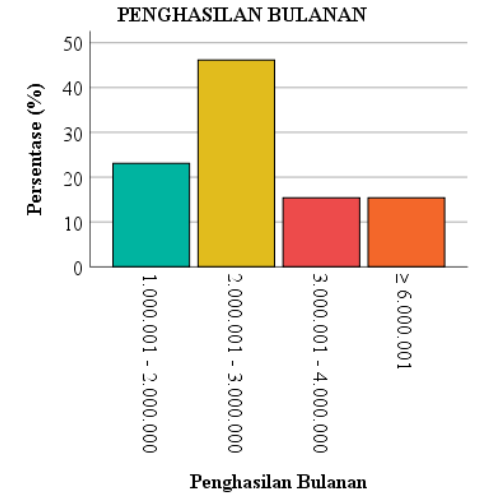

Gambar 13. Penghasilan bulanan responden pada Stasiun Jurang Mangu

\section{Karakteristik perjalanan responden}

- Maksud Perjalanan

Data maksud perjalanan responden pada penelitian ini dapat dilihat pada Gambar 14 dan Gambar 15.

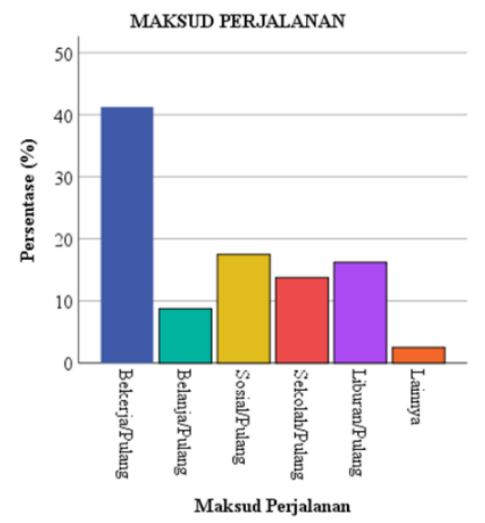

Gambar 14. Maksud perjalanan responden KRL Green Line

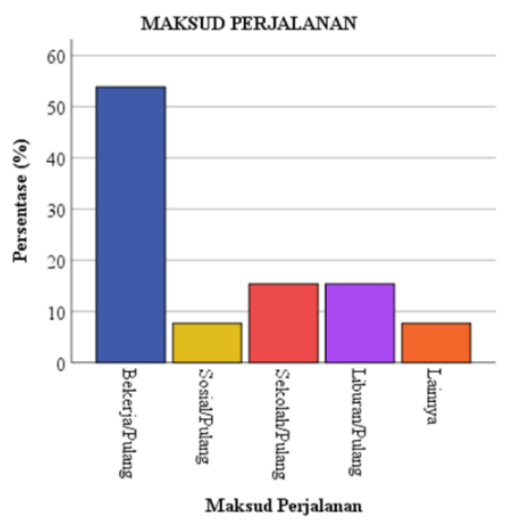

Gambar 15. Maksud perjalanan responden pada Stasiun Jurang Mangu

- Frekuensi penggunaan KRL

Data frekuensi penggunaan KRL responden pada penelitian ini dapat dilihat pada Gambar 16 dan Gambar 17.

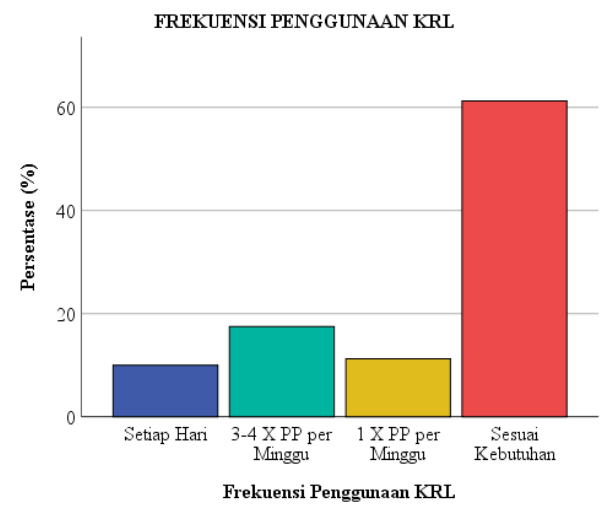

Gambar 16. Frekuensi Penggunaan KRL Green Line

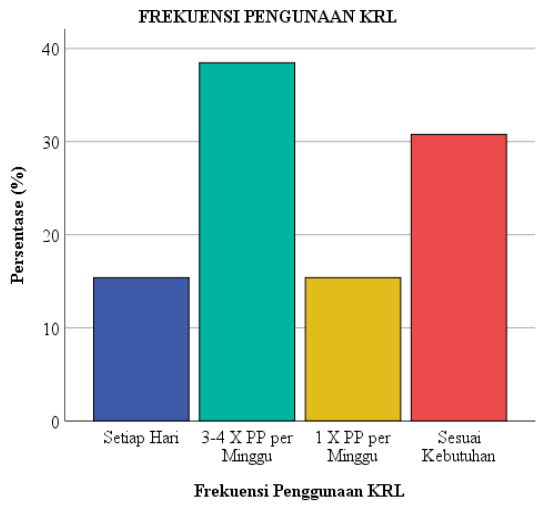

Gambar 17. Frekuensi Penggunaan KRL melalui Stasiun Jurang Mangu 
- Stasiun keberangkatan

Data stasiun keberangkatan responden pada penelitian ini dapat dilihat pada Gambar 18.

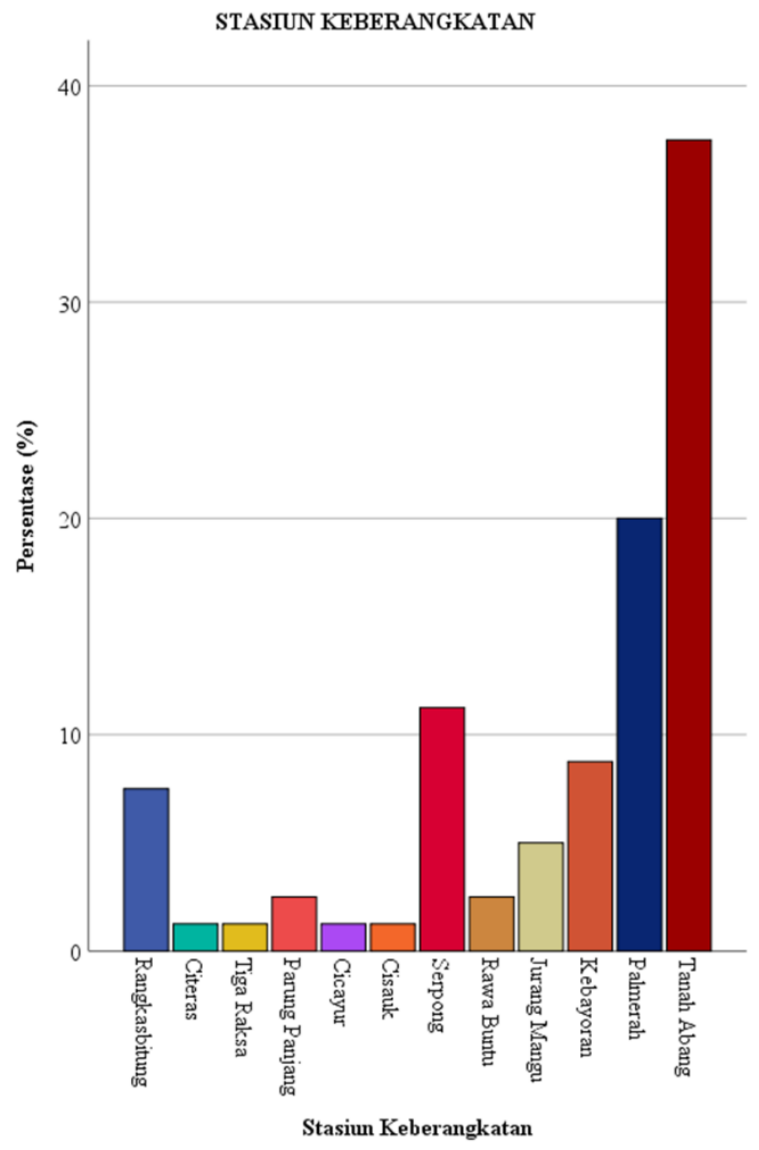

Gambar 18. Stasiun keberangkatan responden KRL Green Line
- Stasiun tujuan

Data stasiun tujuan responden pada penelitian ini dapat dilihat pada Gambar 19.

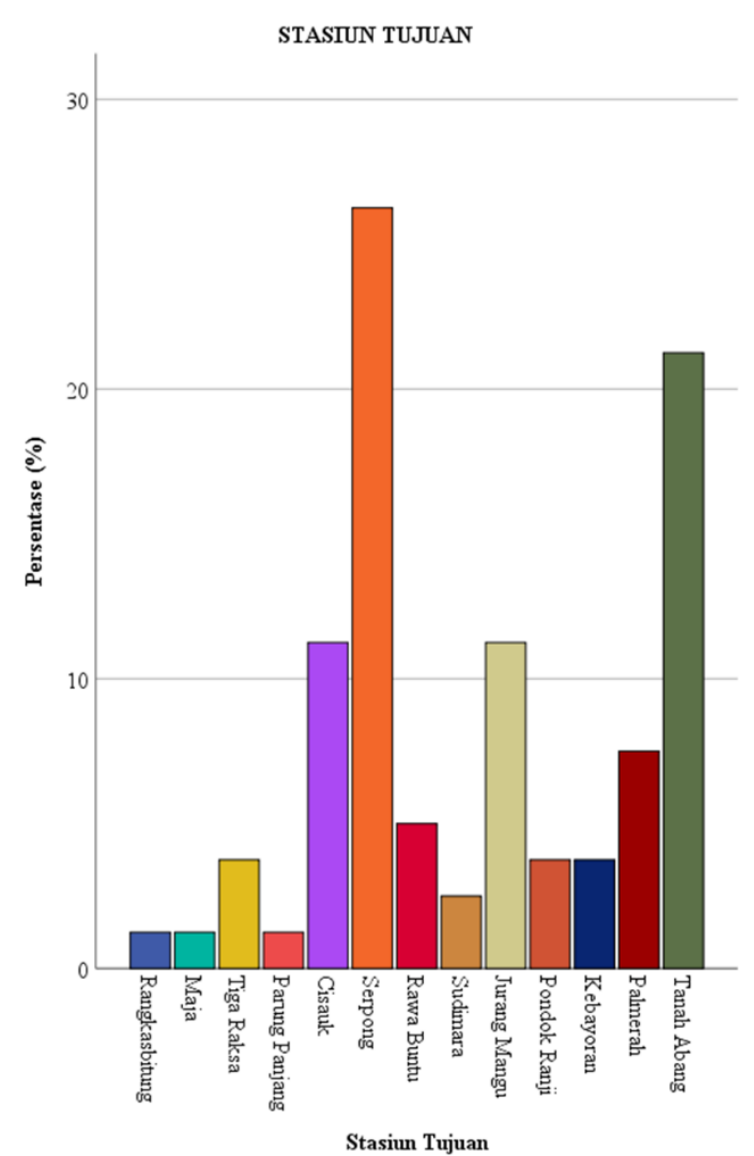

Gambar 19. Stasiun tujuan responden KRL Green Line

- Moda menuju/dari stasiun

Data maksud perjalanan responden pada penelitian ini dapat dilihat pada Gambar 20 dan Gambar 21.

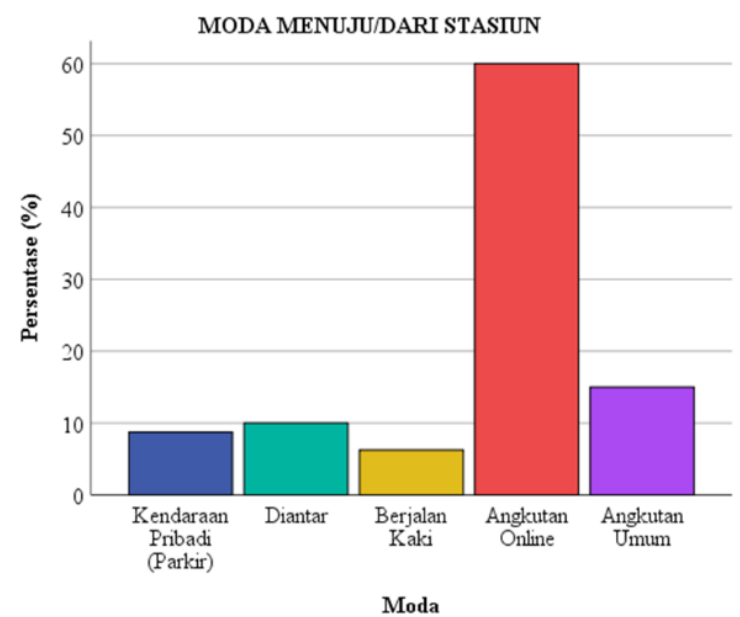

Gambar 20. Moda responden menuju/dari Stasiun KRL Green Line

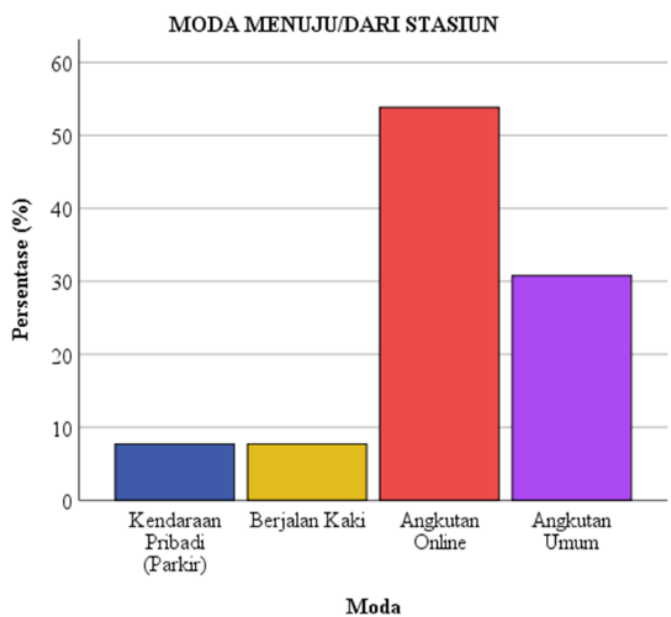

Gambar 21. Moda responden menuju/dari Stasiun Jurang Mangu 
- Biaya transportasi

Data biaya transportasi responden pada penelitian ini dapat dilihat pada Gambar 22 dan Gambar 23.

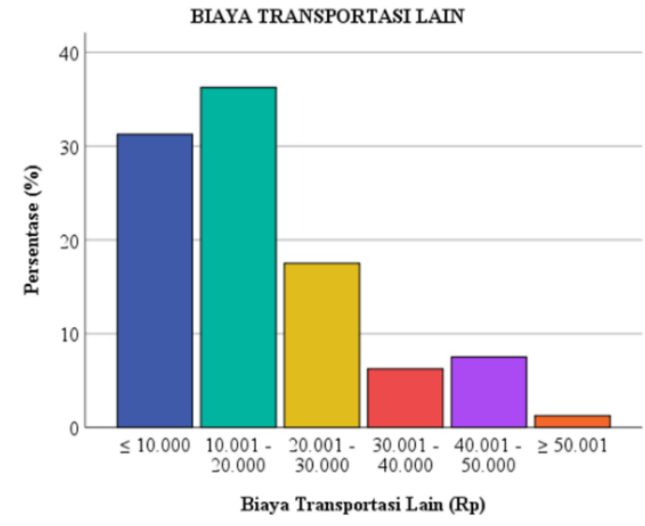

Gambar 22. Biaya transportasi lain responden KRL Green Line

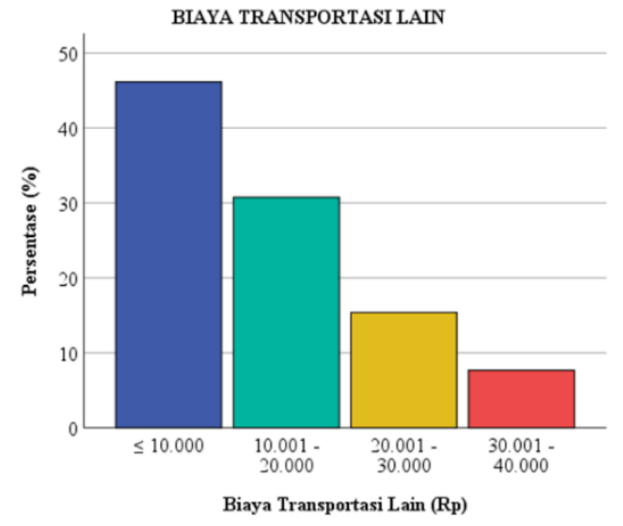

Gambar 23. Biaya transportasi lain responden pada Stasiun Jurang Mangu

\section{Analisis ATP}

- Alasan penggunaan KRL

Data alasan penggunaan KRL responden pada penelitian ini dapat dilihat pada Gambar 24 dan Gambar 25.

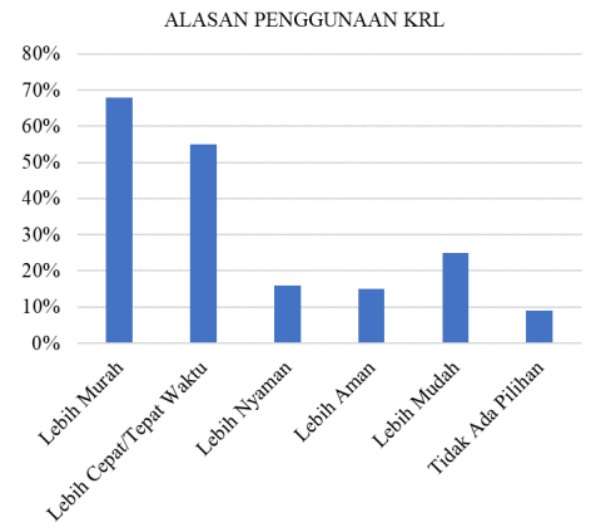

Gambar 24. Alasan penggunaan KRL Green Line

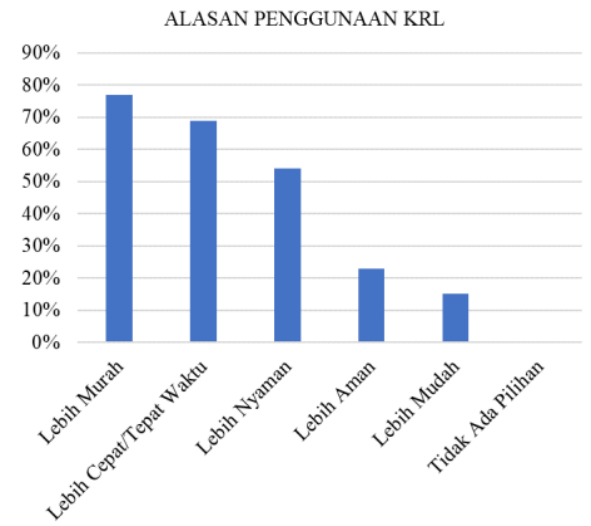

Gambar 25. Alasan penggunaan KRL melalui Stasiun Jurang Mangu

- Besaran nilai ATP

Data frekuensi ATP responden KRL Green Line dapat dilihat pada Tabel 2.

Tabel 2. Frekuensi ATP responden KRL Green Line

\begin{tabular}{cccccccc}
\hline \multirow{2}{*}{ ATP } & \multicolumn{5}{c}{ Tarif Dasar (Rp) } & \multicolumn{2}{c}{ Total } \\
\cline { 2 - 7 } & 3000 & 4000 & 5000 & 6000 & 7000 & 8000 & \\
\hline Tarif Saat Ini (Tetap) & 56 & 13 & 4 & 2 & 1 & 4 & 80 \\
Tarif Naik Rp. 1.000,- & 54 & 11 & 3 & 2 & 1 & 4 & 75 \\
Tarif Naik Rp. 2.000,- & 48 & 10 & 3 & 2 & 1 & 4 & 68 \\
Tarif Naik Rp. 3.000,- & 33 & 9 & 3 & 1 & 1 & 4 & 51 \\
Tarif Naik Rp. 4.000,- & 21 & 7 & 3 & 1 & 1 & 3 & 36 \\
Tarif Naik Rp. 5.000,- & 17 & 5 & 2 & 1 & 1 & 3 & 29 \\
\hline
\end{tabular}


Data persentase ATP responden KRL Green Line dapat dilihat pada Tabel 3.

Tabel 3. Persentase ATP responden KRL Green Line

\begin{tabular}{cccccccc}
\hline \multirow{2}{*}{ ATP } & \multicolumn{3}{c}{ Tarif Dasar (Rp) } & \multicolumn{2}{c}{ Total } \\
\cline { 2 - 7 } & 3000 & 4000 & 5000 & 6000 & 7000 & 8000 & \\
\hline Tarif Saat Ini (Tetap) & $70 \%$ & $16 \%$ & $5 \%$ & $3 \%$ & $1 \%$ & $5 \%$ & $100 \%$ \\
Tarif Naik Rp. 1.000,- & $67 \%$ & $14 \%$ & $4 \%$ & $3 \%$ & $1 \%$ & $5 \%$ & $94 \%$ \\
Tarif Naik Rp. 2.000,- & $60 \%$ & $12 \%$ & $4 \%$ & $3 \%$ & $1 \%$ & $5 \%$ & $85 \%$ \\
Tarif Naik Rp. 3.000,- & $42 \%$ & $11 \%$ & $4 \%$ & $1 \%$ & $1 \%$ & $5 \%$ & $64 \%$ \\
Tarif Naik Rp. 4.000,- & $26 \%$ & $9 \%$ & $4 \%$ & $1 \%$ & $1 \%$ & $4 \%$ & $45 \%$ \\
Tarif Naik Rp. 5.000,- & $21 \%$ & $6 \%$ & $3 \%$ & $1 \%$ & $1 \%$ & $4 \%$ & $36 \%$ \\
\hline
\end{tabular}

Data frekuensi dan persentase ATP responden Stasiun Jurang Mangu masing-masing dapat dilihat pada Tabel 4 dan Tabel 5.

Tabel 4. Frekuensi ATP responden Stasiun Jurang Mangu

\begin{tabular}{cc}
\hline ATP & $\begin{array}{c}\text { Tarif Dasar } \\
\text { Rp. 3.000,- }\end{array}$ \\
\hline Tarif Saat Ini (Tetap) & 13 \\
Tarif Naik Rp. 1.000,- & 13 \\
Tarif Naik Rp. 2.000,- & 13 \\
Tarif Naik Rp. 3.000,- & 7 \\
Tarif Naik Rp. 4.000,- & 5 \\
Tarif Naik Rp. 5.000,- & 5
\end{tabular}

Tabel 5. Persentase ATP responden Stasiun Jurang Mangu

\begin{tabular}{cc}
\hline ATP & $\begin{array}{c}\text { Tarif Dasar } \\
\text { Rp. 3.000,- }\end{array}$ \\
\hline Tarif Saat Ini (Tetap) & $100 \%$ \\
Tarif Naik Rp. 1.000,- & $100 \%$ \\
Tarif Naik Rp. 2.000,- & $100 \%$ \\
Tarif Naik Rp. 3.000,- & $54 \%$ \\
Tarif Naik Rp. 4.000,- & $39 \%$ \\
Tarif Naik Rp. 5.000,- & $39 \%$ \\
\hline
\end{tabular}

Besaran nilai ATP rata-rata KRL Green Line terhadap tingkat tarif saat ini selengkapnya dapat dilihat pada Tabel 6 dan besaran nilai ATP rata-rata pada Stasiun Jurang Mangu terhadap tingkat tarif saat ini selengkapnya dapat dilihat pada Tabel 7. Berikut adalah contoh perhitungan besaran nilai ATP rata-rata KRL Green Line untuk tarif dasar Rp. 3.000,- berdasarkan Persamaan 1.
ATP Rata-rata KRL Green Line =
$\underline{3000 \times 56+4000 \times 54+5000 \times 48+6000 \times 33+7000 \times 21+8000 \times 17}$$$
=\quad \text { Rp. } 4.825,-
$$

Tabel 6. ATP rata-rata KRL Green Line

\begin{tabular}{ccc}
\hline $\begin{array}{c}\text { Tarif Dasar } \\
(\mathrm{Rp})\end{array}$ & $\begin{array}{c}\text { ATP Rata-rata } \\
(\mathrm{Rp})\end{array}$ & $\begin{array}{c}\text { Potensi } \\
\text { Kenaikan Tarif } \\
(\mathrm{Rp})\end{array}$ \\
\hline 3000 & 4825 & 1825 \\
4000 & 6018 & 2018 \\
5000 & 7222 & 2222 \\
6000 & 8000 & 2000 \\
7000 & 9500 & 2500 \\
8000 & 10318 & 2318 \\
\hline
\end{tabular}

Tabel 7. ATP rata-rata pada Stasiun Jurang Mangu

\begin{tabular}{ccc}
\hline $\begin{array}{c}\text { Tarif Dasar } \\
(\mathrm{Rp})\end{array}$ & $\begin{array}{c}\text { ATP Rata-rata } \\
(\mathrm{Rp})\end{array}$ & $\begin{array}{c}\text { Potensi } \\
\text { Kenaikan Tarif } \\
(\mathrm{Rp})\end{array}$ \\
\hline 3000 & 4875 & 1875 \\
4000 & - & - \\
5000 & - & - \\
6000 & - & - \\
7000 & - & - \\
8000 & - & - \\
\hline
\end{tabular}


- Sensitivitas besaran nilai ATP

Sensitivitas besaran nilai ATP responden KRL Green Line dapat dilihat pada Gambar 26 dan Gambar 27.

SENSITIVITAS ATP (FREKUENSI)

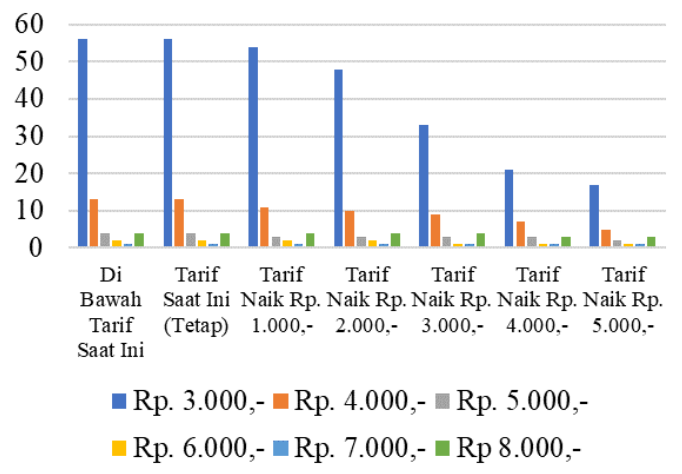

Gambar 26. Sensitivitas ATP (frekuensi) KRL Green Line

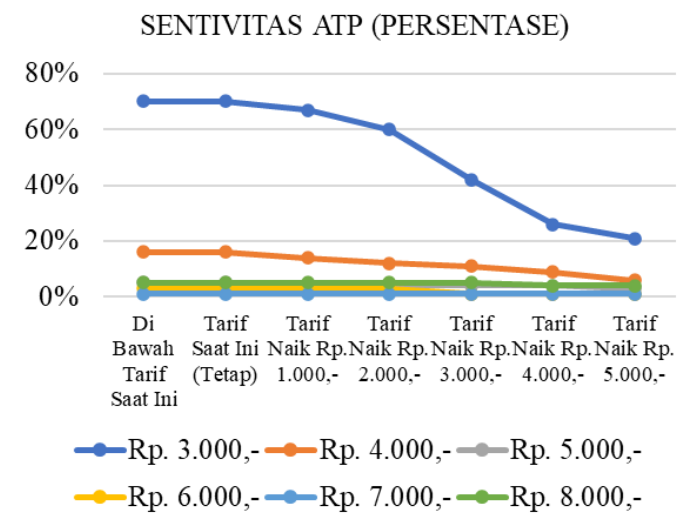

Gambar 27. Sensitivitas ATP (persentase) KRL Green Line

Sensitivitas besaran nilai ATP responden Stasiun Jurang Mangu dapat dilihat pada Gambar 28 dan Gambar 29.

SENSITIVITAS ATP (FREKUENSI)

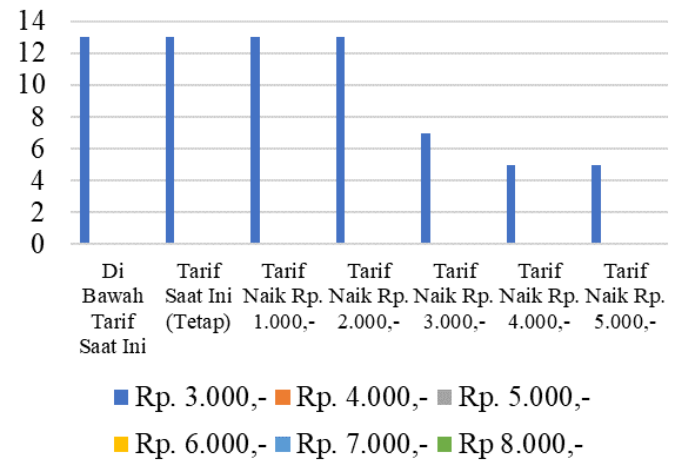

Gambar 28. Sensitivitas ATP (frekuensi) pada Stasiun Jurang Mangu

\section{SENSITIVITAS ATP (PERSENTASE)}

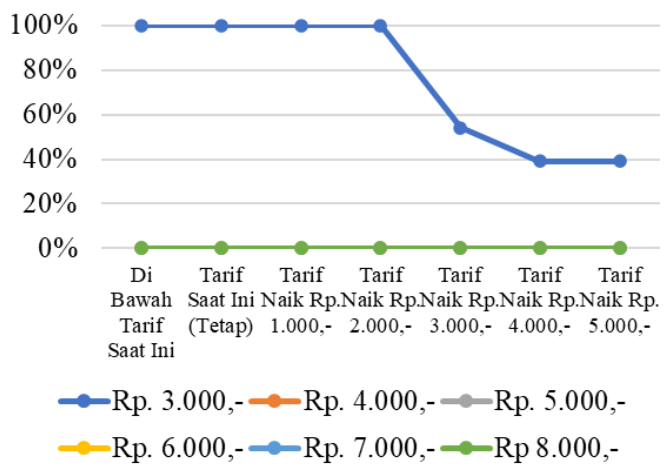

Gambar 29. Sensitivitas ATP (persentase) pada Stasiun Jurang Mangu

\section{Analisis WTP}

- Harapan peningkatan pelayanan KRL

Data harapan peningkatan pelayanan KRL responden pada penelitian ini dapat dilihat pada Gambar 30 dan Gambar 31.

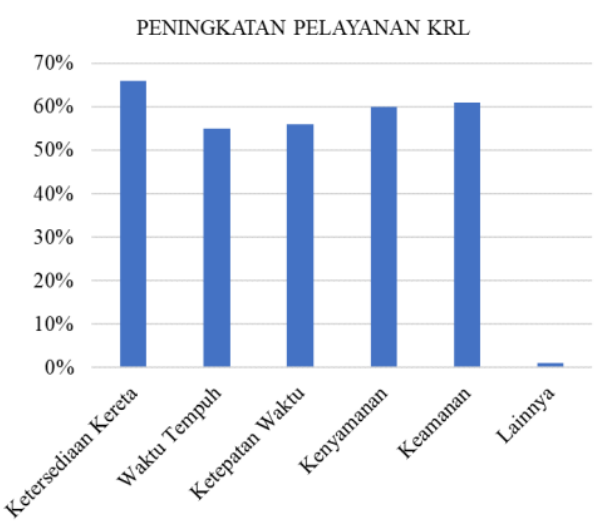

Gambar 30. Peningkatan pelayanan KRL Green Line

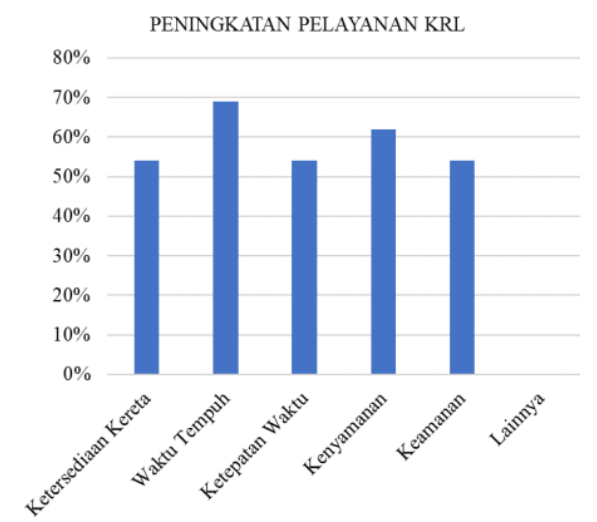

Gambar 31. Peningkatan pelayanan KRL pada Stasiun Jurang Mangu 
- Besaran nilai WTP

Data frekuensi WTP responden KRL Green Line dapat dilihat pada Tabel 8.

Tabel 8. Frekuensi WTP responden KRL Green Line

\begin{tabular}{|c|c|c|c|c|c|c|c|}
\hline \multirow{2}{*}{ WTP } & \multicolumn{6}{|c|}{ Tarif Dasar (Rp) } & \multirow{2}{*}{ Total } \\
\hline & 3000 & 4000 & 5000 & 6000 & 7000 & 8000 & \\
\hline Tarif Saat Ini (Tetap) & 56 & 13 & 4 & 2 & 1 & 4 & 80 \\
\hline Tarif Naik Rp. 1.000,- & 55 & 13 & 3 & 2 & 1 & 4 & 78 \\
\hline Tarif Naik Rp. 2.000,- & 50 & 12 & 3 & 2 & 1 & 4 & 72 \\
\hline Tarif Naik Rp. 3.000,- & 43 & 9 & 3 & 2 & 1 & 4 & 62 \\
\hline Tarif Naik Rp. 4.000,- & 35 & 6 & 3 & 1 & 1 & 4 & 50 \\
\hline Tarif Naik Rp. 5.000,- & 23 & 6 & 2 & 1 & 1 & 4 & 37 \\
\hline
\end{tabular}

Data persentase WTP responden KRL Green Line dapat dilihat pada Tabel 9.

Tabel 9. Persentase WTP responden KRL Green Line

\begin{tabular}{|c|c|c|c|c|c|c|c|}
\hline \multirow{2}{*}{ WTP } & \multicolumn{6}{|c|}{ Tarif Dasar (Rp) } & \multirow{2}{*}{ Total } \\
\hline & 3000 & 4000 & 5000 & 6000 & 7000 & 8000 & \\
\hline Tarif Saat Ini (Tetap) & $70 \%$ & $16 \%$ & $5 \%$ & $3 \%$ & $1 \%$ & $5 \%$ & $100 \%$ \\
\hline Tarif Naik Rp. 1.000,- & $69 \%$ & $16 \%$ & $4 \%$ & $3 \%$ & $1 \%$ & $5 \%$ & $98 \%$ \\
\hline Tarif Naik Rp. 2.000,- & $62 \%$ & $15 \%$ & $4 \%$ & $3 \%$ & $1 \%$ & $5 \%$ & $90 \%$ \\
\hline Tarif Naik Rp. 3.000,- & $54 \%$ & $11 \%$ & $4 \%$ & $3 \%$ & $1 \%$ & $5 \%$ & $78 \%$ \\
\hline Tarif Naik Rp. 4.000,- & $44 \%$ & $8 \%$ & $4 \%$ & $1 \%$ & $1 \%$ & $5 \%$ & $63 \%$ \\
\hline Tarif Naik Rp. 5.000,- & $29 \%$ & $8 \%$ & $2 \%$ & $1 \%$ & $1 \%$ & $5 \%$ & $46 \%$ \\
\hline
\end{tabular}

Data frekuensi dan persentase WTP responden Stasiun Jurang Mangu masing-masing dapat dilihat pada Tabel 10 dan Tabel 11.

Tabel 10. Frekuensi WTP responden Stasiun Jurang Mangu

\begin{tabular}{cc}
\hline WTP & $\begin{array}{c}\text { Tarif Dasar } \\
\text { Rp. 3.000,- }\end{array}$ \\
\hline Tarif Saat Ini (Tetap) & 13 \\
Tarif Naik Rp. 1.000,- & 13 \\
Tarif Naik Rp. 2.000,- & 13 \\
Tarif Naik Rp. 3.000,- & 7 \\
Tarif Naik Rp. 4.000,- & 5 \\
Tarif Naik Rp. 5.000,- & 5 \\
\hline
\end{tabular}

Tabel 11. Persentase WTP responden Stasiun Jurang Mangu

\begin{tabular}{cc}
\hline WTP & $\begin{array}{c}\text { Tarif Dasar } \\
\text { Rp. 3.000,- }\end{array}$ \\
\hline Tarif Saat Ini (Tetap) & $100 \%$ \\
Tarif Naik Rp. 1.000,- & $100 \%$ \\
Tarif Naik Rp. 2.000,- & $100 \%$ \\
Tarif Naik Rp. 3.000,- & $54 \%$ \\
Tarif Naik Rp. 4.000,- & $39 \%$ \\
Tarif Naik Rp. 5.000,- & $39 \%$ \\
\hline
\end{tabular}

Besaran nilai WTP rata-rata KRL Green Line terhadap tingkat tarif jika ada peningkatan pelayanan selengkapnya dapat dilihat pada Tabel 12 dan besaran nilai WTP rata-rata pada Stasiun Jurang Mangu terhadap tingkat tarif jika ada peningkatan pelayanan selengkapnya dapat dilihat pada Tabel 13. Berikut adalah contoh 
perhitungan besaran nilai WTP rata-rata KRL Green Line untuk tarif dasar Rp. 3.000,- berdasarkan Persamaan 2.

$\begin{aligned} \text { WTP Rata-rata KRL Green Line } & =\frac{3000 \times 56+4000 \times 55+5000 \times 50+6000 \times 43+7000 \times 35+8000 \times 23}{56+55+50+43+35+23} \\ & =\quad \text { Rp. } 5.057,-\end{aligned}$

Tabel 12. WTP rata-rata KRL Green Line

\begin{tabular}{ccc}
\hline $\begin{array}{c}\text { Tarif Dasar } \\
(\mathrm{Rp})\end{array}$ & $\begin{array}{c}\text { WTP Rata-rata } \\
(\mathrm{Rp})\end{array}$ & $\begin{array}{c}\text { Potensi } \\
\text { Kenaikan Tarif } \\
(\mathrm{Rp})\end{array}$ \\
\hline 3000 & 5057 & 2057 \\
4000 & 6000 & 2000 \\
5000 & 7222 & 2222 \\
6000 & 8100 & 2100 \\
7000 & 9500 & 2500 \\
8000 & 10500 & 2500 \\
\hline
\end{tabular}

Tabel 13. WTP rata-rata pada Stasiun Jurang Mangu

\begin{tabular}{ccc}
\hline $\begin{array}{c}\text { Tarif Dasar } \\
(\mathrm{Rp})\end{array}$ & $\begin{array}{c}\text { WTP Rata-rata } \\
(\mathrm{Rp})\end{array}$ & $\begin{array}{c}\text { Potensi } \\
\text { Kenaikan Tarif } \\
(\mathrm{Rp})\end{array}$ \\
\hline 3000 & 5167 & 2167 \\
4000 & - & - \\
5000 & - & - \\
6000 & - & - \\
7000 & - & - \\
8000 & - & - \\
\hline
\end{tabular}

- Senstivitas besaran nilai WTP

Sensitivitas besaran nilai WTP responden KRL Green Line dapat dilihat pada Gambar 32 dan Gambar 33.

SENSITIVITAS WTP (FREKUENSI)

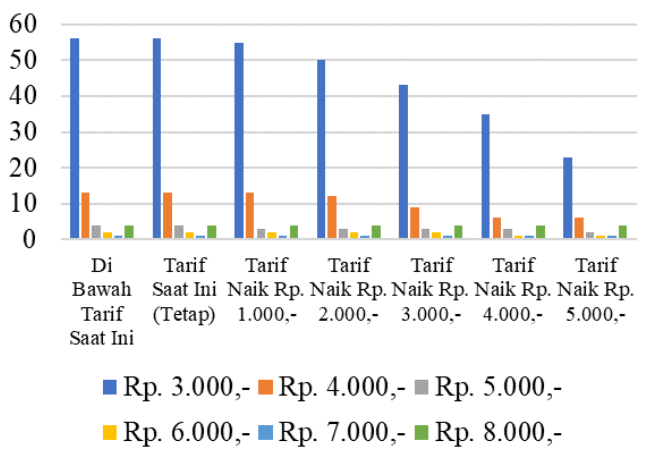

Gambar 32. Sensitivitas WTP (frekuensi) KRL Green Line

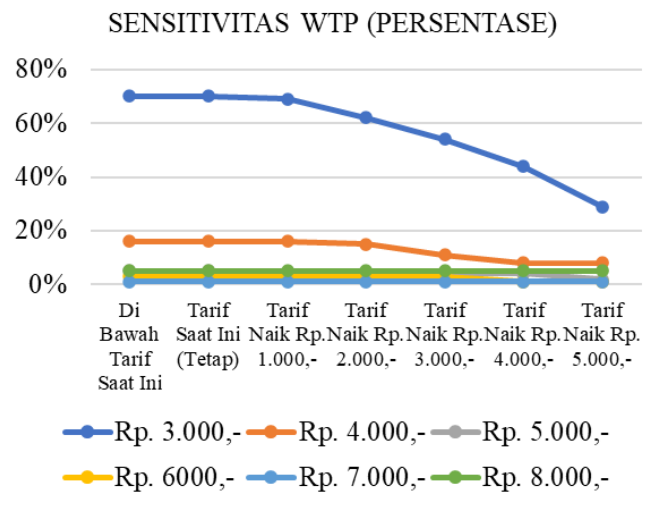

Gambar 33. Sensitivitas WTP (persentase) KRL Green Line

Sensitivitas besaran nilai WTP responden Stasiun Jurang Mangu dapat dilihat pada Gambar 34 dan Gambar 35 .

\section{SENSITIVITAS ATP (FREKUENSI)}

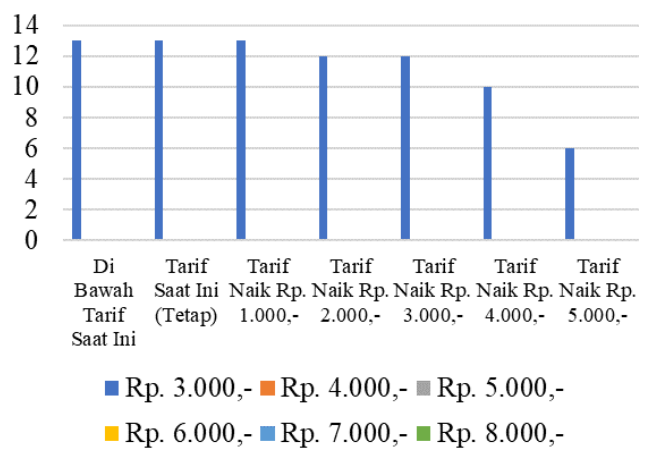

Gambar 34. Sensitivitas WTP (frekuensi) pada Stasiun Jurang Mangu
SENSITIVITAS WTP (PERSENTASE)

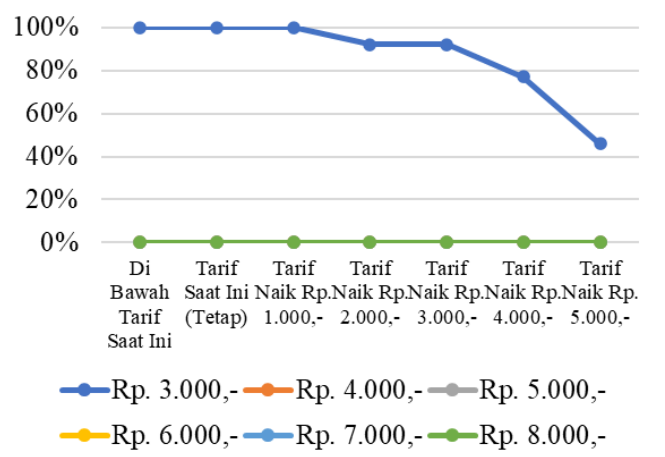

Gambar 35. Sensitivitas WTP (persentase) pada Stasiun Jurang Mangu 


\section{Analisis ATP dan WTP terhadap tarif KRL Green Line}

Besaran nilai ATP rata-rata dan WTP rata-rata responden terhadap tarif KRL dapat dilihat pada Tabel 14 dan Tabel 15.

Tabel 14. ATP dan WTP terhadap tarif KRL Green Line

\begin{tabular}{ccc}
\hline $\begin{array}{c}\text { Tarif Dasar } \\
(\mathrm{Rp})\end{array}$ & $\begin{array}{c}\text { ATP Rata-rata } \\
(\mathrm{Rp})\end{array}$ & $\begin{array}{c}\text { WTP Rata-rata } \\
(\mathrm{Rp})\end{array}$ \\
\hline 3000 & 4825 & 5057 \\
4000 & 6018 & 6000 \\
5000 & 7222 & 7222 \\
6000 & 8000 & 8100 \\
7000 & 9500 & 9500 \\
8000 & 10318 & 10500 \\
\hline
\end{tabular}

Tabel 15. ATP dan WTP terhadap tarif KRL pada Stasiun Jurang Mangu

\begin{tabular}{ccc}
\hline $\begin{array}{c}\text { Tarif Dasar } \\
(\mathrm{Rp})\end{array}$ & $\begin{array}{c}\text { ATP Rata-rata } \\
(\mathrm{Rp})\end{array}$ & $\begin{array}{c}\text { WTP Rata-rata } \\
(\mathrm{Rp})\end{array}$ \\
\hline 3000 & 4875 & 5167 \\
4000 & - & - \\
5000 & - & - \\
6000 & - & - \\
7000 & - & - \\
8000 & - & - \\
\hline
\end{tabular}

Sensitivitas besaran nilai ATP rata-rata dan WTP rata-rata responden terhadap tarif KRL dapat dilihat pada Gambar 36 dan Gambar 37.

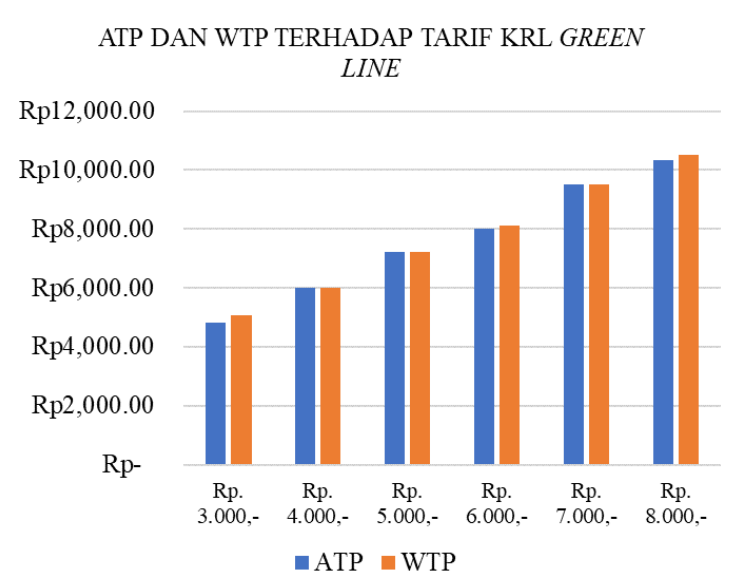

Gambar 36. Sensitivitas ATP dan WTP terhadap tarif KRL Green Line

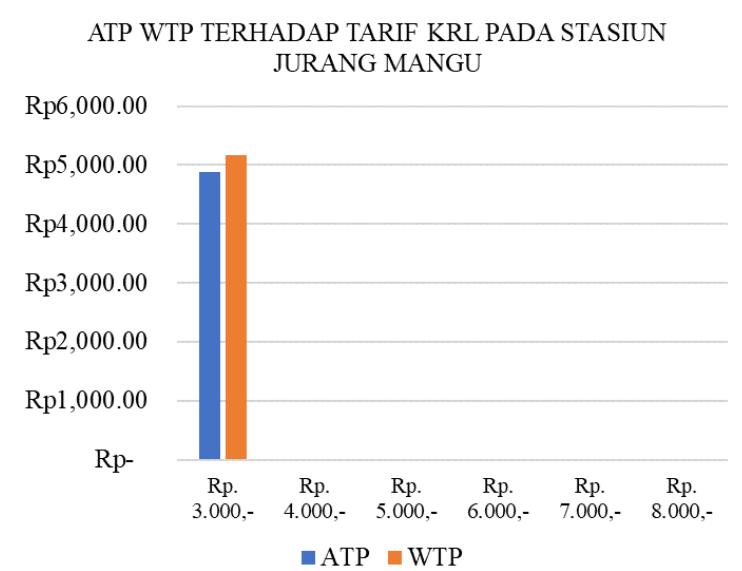

Gambar 37. Sensitivitas ATP dan WTP terhadap tarif KRL pada Stasiun Jurang Mangu

Berikut adalah pembahasan dari analisis ATP dan WTP terhadap tarif KRL Green Line:

- Pengguna KRL Green Line untuk tingkat tarif dasar Rp. 3.000,- diperoleh nilai ATP rata-rata = Rp. 4.825,dan nilai WTP rata-rata $=$ Rp. 5.057,-. Data ini menunjukkan nilai WTP $>$ ATP $>$ tarif dasar sehingga terdapat keleluasaan untuk menaikkan tarif sebesar Rp. 1.825,- sampai dengan nilai ATP rata-rata atau sebesar Rp. 2.057,- sampai dengan nilai WTP rata-rata.

- Pengguna KRL yang melalui Stasiun Jurang Mangu untuk tingkat tarif dasar Rp. 3.000,- diperoleh nilai ATP rata-rata $=$ Rp. 4.875,- dan nilai WTP rata-rata $=$ Rp. 5.167,-. Data ini menunjukkan nilai WTP $>$ ATP $>$ tarif dasar sehingga terdapat keleluasaan untuk menaikkan tarif sebesar Rp. 1.875,- sampai dengan nilai ATP ratarata atau sebesar Rp. 2.167,-- sampai dengan nilai WTP rata-rata.

\section{KESIMPULAN DAN SARAN}

\section{Kesimpulan}

Hasil dan pembahasan dari analisis penelitian ini dapat diambil beberapa kesimpulan:

- Mayoritas pengguna KRL Green Line dikenakan pada tingkat tarif dasar sebesar Rp. 3.000,- dengan jangkauan jarak kurang dari $25 \mathrm{~km}$. 
- Faktor utama penggunaan KRL Green Line didasari oleh tarif yang lebih murah jika mengacu pada ATP dan peningkatan ketersediaan kereta dari segi WTP.

- Analisis ATP KRL Green Line yang melalui Stasiun Jurang Mangu pada tingkat tarif dasar Rp. 3.000,memperlihatkan tingkat kesetujuan terhadap kenaikan tarif Rp. 1.000,- sebesar 100\%, kenaikan tarif Rp. 2.000,- sebesar 100\%, kenaikan tarif Rp. 3.000,- sebesar 54\%, kenaikan tarif Rp. 4.000,- sebesar 39\%, dan kenaikan tarif Rp. 5.000,- sebesar 39\%.

- Analisis WTP KRL Green Line yang melalui Stasiun Jurang Mangu pada tingkat tarif dasar Rp. 3.000,memperlihatkan tingkat kesetujuan terhadap kenaikan tarif Rp. 1.000,- sebesar 100\%, kenaikan tarif Rp. 2.000,- sebesar 92\%, kenaikan tarif Rp. 3.000,- sebesar 92\%, kenaikan tarif Rp. 4.000,- sebesar 77\%, dan kenaikan tarif Rp. 5.000,- sebesar 46\%.

- Nilai ATP rata-rata dan WTP rata-rata KRL Green Line terhadap tingkat tarif eksisting sebesar Rp. 3.000,masing-masing adalah Rp. 4.825,- dan Rp. 5.057,-., sedangkan untuk yang melalui Stasiun Jurang Mangu masing-masing adalah Rp. 4.875,- dan Rp. 5.167,--

- Sensitivitas nilai ATP rata-rata dan WTP rata-rata KRL Green Line terdapat $100 \%$ penumpang yang mampu membayar dan $100 \%$ penumpang yang mau membayar tarif eksisting, kondisi ini menunjukkan bahwa tarif yang berlaku saat ini sebanding dengan pelayanan yang diterima.

\section{Saran}

Berikut ini adalah beberapa saran yang penulis berikan untuk arah perkembangan selanjutnya:

- Tarif KRL Green Line yang berlaku saat ini lebih rendah dari besaran nilai ATP yang diperoleh, sehingga pemerintah mempunyai potensi untuk menaikkan tarif dengan asumsi biaya operasi relatif stabil.

- Tarif KRL Green Line yang berlaku saat ini lebih rendah dari besaran nilai WTP yang diperoleh, sehingga pemerintah mempunyai potensi untuk menaikkan tarif dengan mempertimbangkan ketersediaan kereta api dan waktu tempuh.

- Penelitian ini dilaksanakan pada saat pandemi covid-19 yang terjadi di Indonesia sehingga peneliti tidak dapat melalukan survei lapangan, untuk mengatasi masalah tersebut peneliti melaksanakan survei secara online untuk mendapatkan responden yang dimaksud. Peneliti menyadari penggunaan survei secara online memiliki keterbatasan tertentu, sehingga untuk mendapatkan hasil yang lebih baik diperlukan penelitian lebih lanjut secara onboard ataupun offboard terhadap pengguna KRL Green Line.

\section{DAFTAR PUSTAKA}

Basuki, Imam dan Steven Chuadinata. “Analisis Ability To Pay dan Willingness to Pay Jasa Kereta Api." Spektran (2019): 140-146.

Fricilia, Maya dan Slamet Jauhari Legowo. "Evaluasi Penerapan Tarif Angkutan Umum Kereta Api (Studi Kasus Kereta Api Madiun Jaya Ekspres).” Matriks Teknik Sipil (2013): 46-53.

Hariwahyudi, Risky, Dewi Fatmawati Suprapto dan Siti Malkhamah. "Pelayanan dan Tarif Kereta Api Perkotaan." Transportasi (2016): 173-182.

Risdyanto, Edo Fasha Nasution dan Erni Ummi Hasanah. "Kinerja Teknis dan Analisis ATP WTP Angkutan Trans Jogja." (2016).

Safitri, Revy. "Evalutasi Tarif Angkutan Umum Berdasarkan Ability To Pay (ATP) dan Willingness To Pay (WTP) di Kota Pangkalpinang." Fropil (2016).

Setiyaningsih, Ika, Siti Hajar Asari dan Zilhardi Idris. "Evaluasi Tarif Kereta Api Malabar Kelas Ekonomi Menurut ATP dan WTP Penggunanya.” (2019).

Siregar, Muchtarudin. Beberapa Masalah Ekonomi dan Manajemen Transportasi. Jakarta: Fakultas Ekonomi Universitas Indonesia, 2012.

Sitorus, Fredy Jhon Philip, Ferdinand Fassa dan Fitriyah Nurhidayah. "Analisis Kesediaan Membayar Kereta Commuter Line Terhadap Peningkatan Kualitas Pelayanan di Stasiun Cikarang.” (2018).

Tamin, Ofyar Z. "Evaluasi Tarif Angkutan Umum dan Analisis Abilitiy To Pay (ATP) dan Willingness To Pay (WTP) di DKI Jakarta.” Transportasi Forum Studi Transportasi Antar Perguruan Tinggi (FSTPT) (1999). 
Winaya, Amrita dan Jenny Caroline. "Analisis Tarif Kereta Komuter Surabaya-Porong Ditinjau dari Kemampuan dan Kemauan Membayar (ATP dan WTP) Pengguna Jasa.” (2019). 